LA-14343

Approved for public release;

distribution is unlimited.

Review of the Geologic and Structural

Setting near the Site of the Proposed Transuranic

Waste Facility (TRUWF) Technical Area 52 (TA-52),

Los Alamos National Laboratory 
Funded by Environmental Management Program Projects.

Edited by Mable Amador, Group IRM-CAS.

Photocomposition by Deidré A. Plumlee, Group IRM-CAS.

Los Alamos National Laboratory, an affirmative action/ equal opportunity employer, is operated by Los Alamos National Security, LLC, for the National Nuclear Security Administration of the U.S. Department of Energy under contract DE-AC52-06NA25396.

This report was prepared as an account of work sponsored by an agency of the U.S. Government. Neither Los Alamos National Security, LLC, the U.S. Government nor any agency thereof, nor any of their employees make any warranty, express or implied, or assume any legal liability or responsibility for the accuracy, completeness, or usefulness of any information, apparatus, product, or process disclosed, or represent that its use would not infringe privately owned rights. Reference herein to any specific commercial product, process, or service by trade name, trademark, manufacturer, or otherwise does not necessarily constitute or imply its endorsement, recommendation, or favoring by Los Alamos National Security, LLC, the U.S. Government, or any agency thereof. The views and opinions of authors expressed herein do not necessarily state or reflect those of Los Alamos National Security, LLC, the U.S. Government, or any agency thereof. Los Alamos National Laboratory strongly supports academic freedom and a researcher's right to publish; as an institution, however, the Laboratory does not endorse the viewpoint of a publication or guarantee its technical correctness. 
LA-14343

Issued: October 2007

Review of the Geologic and Structural

Setting near the Site of the Proposed Transuranic

Waste Facility (TRUWF) Technical Area 52 (TA-52),

Los Alamos National Laboratory

Emily S. Schultz-Fellenz

Jamie N. Gardner 



\section{TABLE OF CONTENTS}

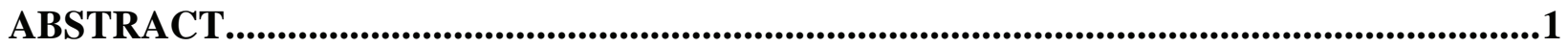

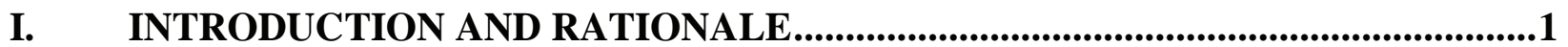

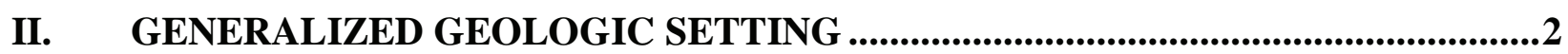

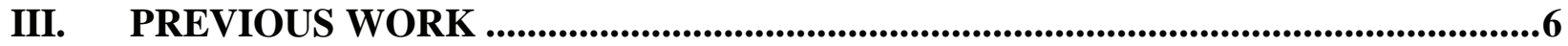

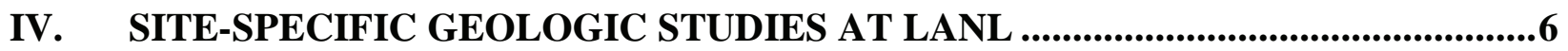

IV.A. Evaluation of the Potential for Surface Faulting at TA-63.................................9

IV.B. Conceptual Design Report for the TA-50 Radioactive Liquid Waste Treatment Facility (RLWTF) Upgrade Project......................................................9

IV.C. Seismic Hazards Investigations at and near TA-55 ........................................9

IV.D. Surficial Materials and Structure at Pajarito Mesa, TA-67 ..............................10

IV.E. Fracture Characteristics in a Disposal Pit on Mesita del Buey, TA-54..........11

IV.F. Geology of the North-Central to Northeastern Portion of LANL, TA-53......11

V. EFFICACY OF FUTURE PALEOSEISMIC STUDIES AT SITE OF THE

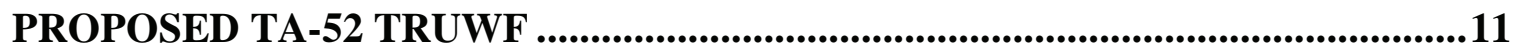

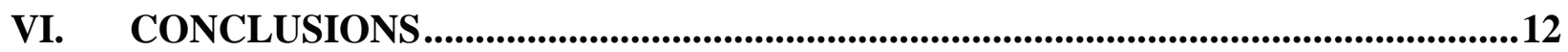

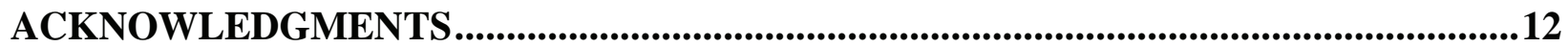

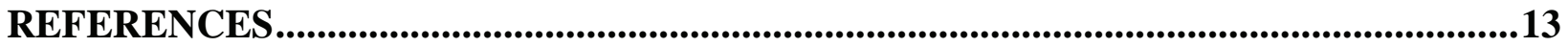

\section{LIST OF FIGURES}

Figure 1. Map of the Rio Grande rift system in northern New Mexico......................................3

Figure 2. Map of the Pajarito fault system in the vicinity of Los Alamos National

Laboratory.

Figure 3. Generalized stratigraphy of the lower units of the Bandelier Tuff and Cerro Toledo interval exposed in the study area..............................................................

Figure 4. Pajarito fault system structural map, with emphasis on subsidiary structures associated with the system.. .........................................................................

Figure 5. Localized geologic map of the TA-52 area, including $200-\mathrm{ft}$ and 3,000-ft standoffs per 40 CFR 264 
This page intentionally left blank. 


\title{
REVIEW OF THE GEOLOGIC AND STRUCTURAL SETTING NEAR THE SITE OF THE PROPOSED TRANSURANIC WASTE FACILITY (TRUWF), TECHNICAL AREA 52 (TA-52), LOS ALAMOS NATIONAL LABORATORY
}

\author{
by \\ Emily S. Schultz-Fellenz and Jamie N. Gardner
}

\begin{abstract}
Because of Los Alamos National Laboratory's proximal location to active geologic structures, assessment of seismic hazards, including the potential for seismic surface rupture, must occur before construction of any facilities housing nuclear or other hazardous materials. A transuranic waste facility (TRUWF) planned for construction at Technical Area 52 (TA-52) provides the impetus for this report. Although no single seismic hazards field investigation has focused specifically on TA-52, numerous studies at technical areas surrounding TA-52 have shown no significant, laterally continuous faults exhibiting activity in the last $10 \mathrm{ka}$ within 3,000 ft of the proposed facility. A site-specific field study at the footprint of the proposed TRUWF would not yield further high-precision data on possible Holocene faulting at the site because post-Bandelier Tuff sediments are lacking and the shallowest subunit contacts of the Bandelier Tuff are gradational. Given the distal location of the proposed TRUWF to any mapped structures with demonstrable Holocene displacement, surface rupture potential appears minimal at TA-52.
\end{abstract}

\section{INTRODUCTION AND RATIONALE}

This document evaluates existing literature documenting previous analyses of stratigraphy, structural geology, and/or seismic hazard in the vicinity of the proposed TRUWF at TA-52 of Los Alamos National Laboratory (LANL). Through this, we provide information on the presence or absence of active faults at the proposed facility site and in surrounding technical areas, as well as an assessment of the potential for seismic surface rupture near the footprint of the proposed facility at TA-52.

Siting, design, and construction of waste facilities at Department of Energy (DOE) sites require compliance with Environmental Protection Agency (EPA) regulations for seismic hazards. Standards and compliance for the proposed TRUWF fall within the auspices of the Resource Conservation and Recovery Act (RCRA) of 1976. Seismic considerations for RCRA location standards are presented in the Code of Federal Regulations, Title 40 (40 CFR) Part 264, Subpart B, "General Facility Standards." Regarding the siting of hazardous waste facilities, 40 CFR 264 states that portions of new facilities where treatment, storage, or disposal of hazardous waste will be conducted must not be located within $200 \mathrm{ft}(61 \mathrm{~m})$ of a fault that has had displacement in Holocene time (within the last 10,000 years). If Holocene faults are present within 3,000 $\mathrm{ft}(914 \mathrm{~m})$ of a proposed facility, a comprehensive geologic analysis of the site is required. 
LANL lies within the Española Basin of the Rio Grande rift (Figure 1), a tectonically active zone of east-west crustal extension along a north-south trending series of asymmetrical basins (e.g., Kelley, 1979; Sanford et al., 1991; Baldridge et al., 1995; Kelson and Olig, 1995). The Rio Grande rift is a major tectonic feature of the North American continent, has been active for at least 30 million years, and continues to be tectonically and magmatically active (e.g., Riecker, 1979; Baldridge et al., 1984; Wolff and Gardner, 1995). In the area of LANL, the Pajarito fault system is the active western margin of the Rio Grande rift. The Pajarito fault system includes the potentially seismogenic Pajarito, Rendija Canyon, and Guaje Mountain faults (Figure 2).

Because of LANL's location relative to active geologic features, seismic hazards, including the potential for seismic surface rupture, must be assessed before construction of any facilities housing nuclear or other hazardous materials. Paleoseismic investigations indicate that there have been three Holocene seismic events of magnitude 6-7 on the Pajarito fault system (Gardner et al., 1990; Wong et al., 1995; Kelson et al., 1996; McCalpin, 1998, 1999; Reneau et al., 2002; Gardner et al., 2003; LANL Seismic Hazards Geology Team, in prep.). The fault system in the western and northern parts of LANL and west of LANL has been mapped in detail to better understand the kinematics of the fault system and to assess the potential for seismic surface rupture at specific Laboratory sites (e.g., Gardner et al., 1998, 1999, 2001; Lewis et al., 2002; Lavine et al., 2003; Schultz et al., 2003, Lewis et al., in review).

\section{GENERALIZED GEOLOGIC SETTING}

The proposed site of the TRUWF at TA-52 (Figure 2) sits atop a sequence of Quaternary-aged rhyolitic ash-flow tuffs collectively called the Tshirege Member of the Bandelier Tuff, east of the principal faults of the Pajarito fault system (Gardner et al., 1999). The Tshirege Member (Qbt) of the Bandelier Tuff is a 1.22 million-year-old complex series of ash-flow tuffs erupted from the Valles Caldera, the eastern rim of which is approximately 10 miles $(\sim 16 \mathrm{~km})$ west of the TA-52 site (age from Izett and Obradovich, 1994; Figure 1). The suite of eruptive subunits that comprise the Tshirege Member includes pyroclastic surge deposits, which in some locations mark contacts between Tshirege Member subunits. In the vicinity of the proposed TRUWF at TA-52, Qbt is generally subdivided into three principal subunits, or cooling units (from top to bottom: Qbt3, Qbt2, and Qbt1; Figure 3), whose contacts are identified by welding characteristics as well as pumice, phenocryst, and lithic characteristics (Broxton and Reneau, 1995; e.g., Gardner et al., 1999; Lewis et al., 2002; Lavine et al., 2003). Physical characteristics of the tuff (including the degree of welding, thickness of cooling units, and postdepositional mineralization) vary with distance from the caldera source. Contacts between the subunits of the Tshirege Member serve as useful markers for determining the presence or absence of faulting (e.g., Gardner et al., 1998, 1999, 2001; Lewis et al., 2002; Lavine et al., 2003; Schultz et al., 2003). 


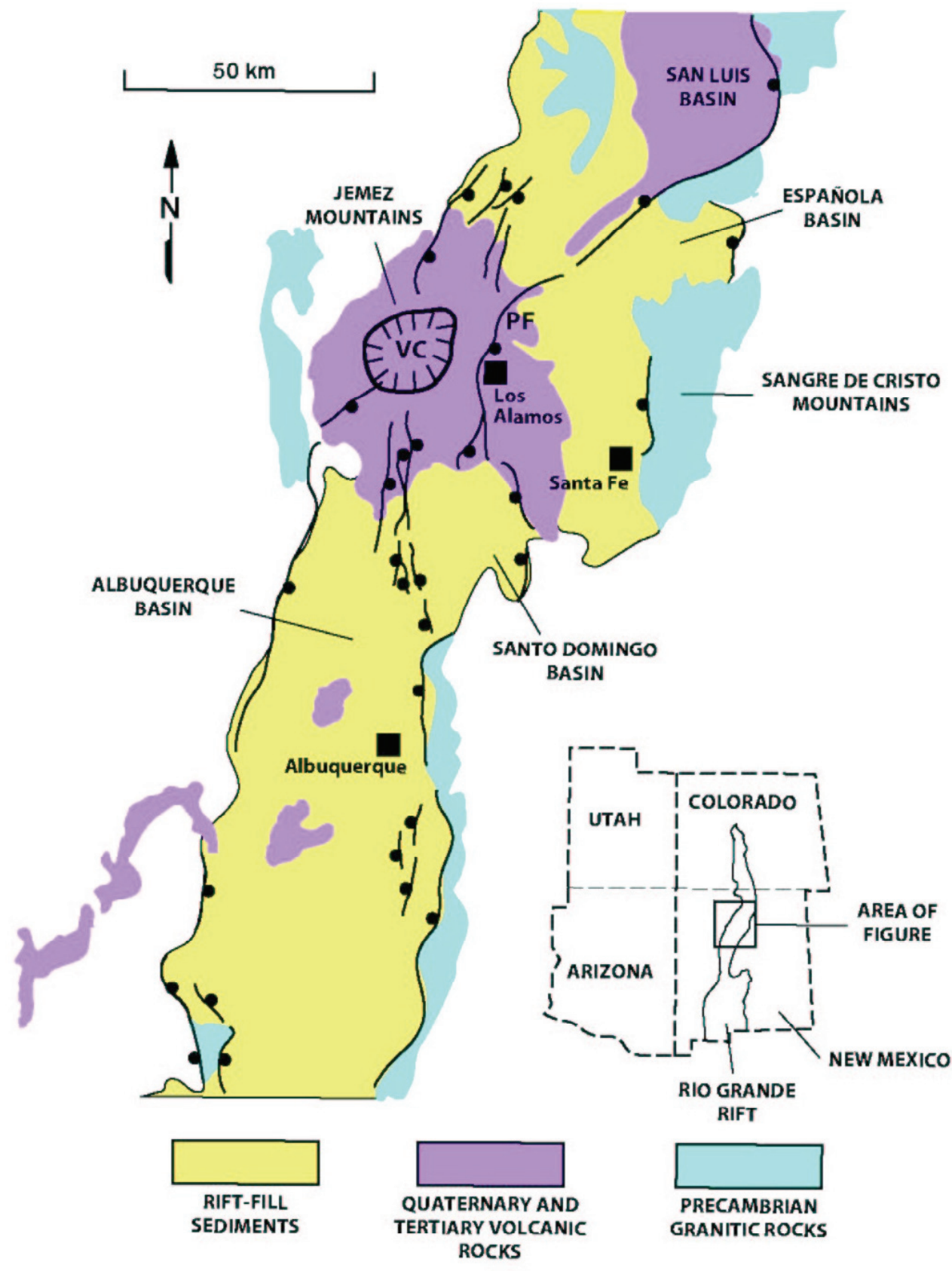

Schultz-Fellenz and Gardner

Figure 1. Map of the Rio Grande rift system in northern New Mexico. Major fault systems are shown schematically, with ball on downthrown block. PF = Pajarito fault.

$\mathrm{VC}=$ Valles-Toledo caldera complex, source of the Quaternary-aged Bandelier Tuff. Modified from Gardner and Goff (1984). 


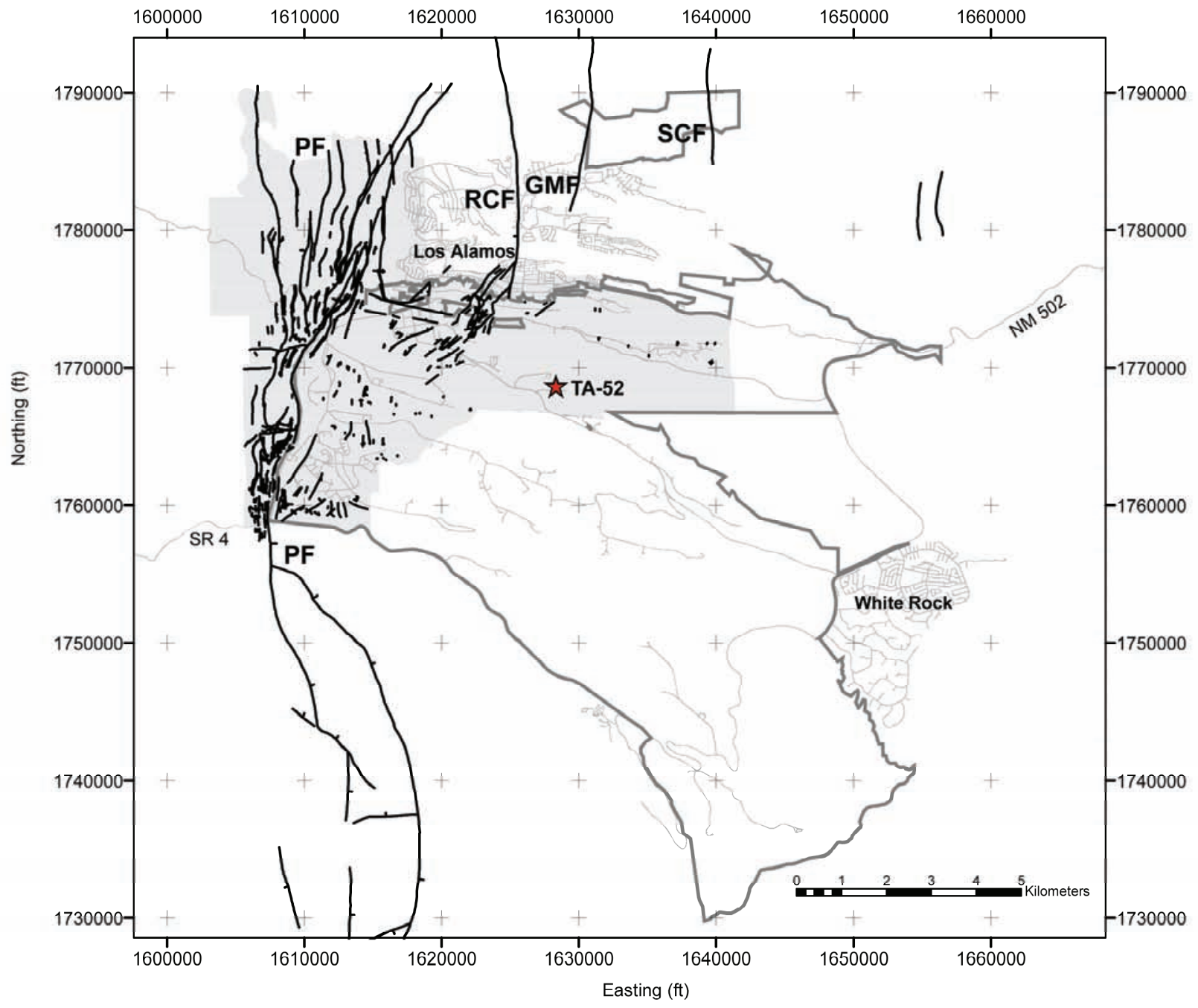

Schultz-Fellenz and Gardner

Figure 2. Map of the Pajarito fault system in the vicinity of Los Alamos National Laboratory. Gray shaded area shows the area that has been mapped in detail to assess potential for faulting at LANL. Dark gray outline shows the extent of LANL. A red star indicates the site of the proposed TRUWF at TA-52. Faults and related folds shown in black are from Gardner and House (1987), Reneau et al. (1995), Gardner et al. (1999, 2001), Lewis et al. (2002), Lavine et al. (2003), Lewis et al. (in review) and Gardner and Reneau (unpublished mapping). Abbreviations: $\mathrm{PF}=$ Pajarito fault; $\mathrm{RCF}=$ Rendija Canyon fault; GMF = Guaje Mountain fault; $\mathrm{SCF}=$ Sawyer Canyon fault. 


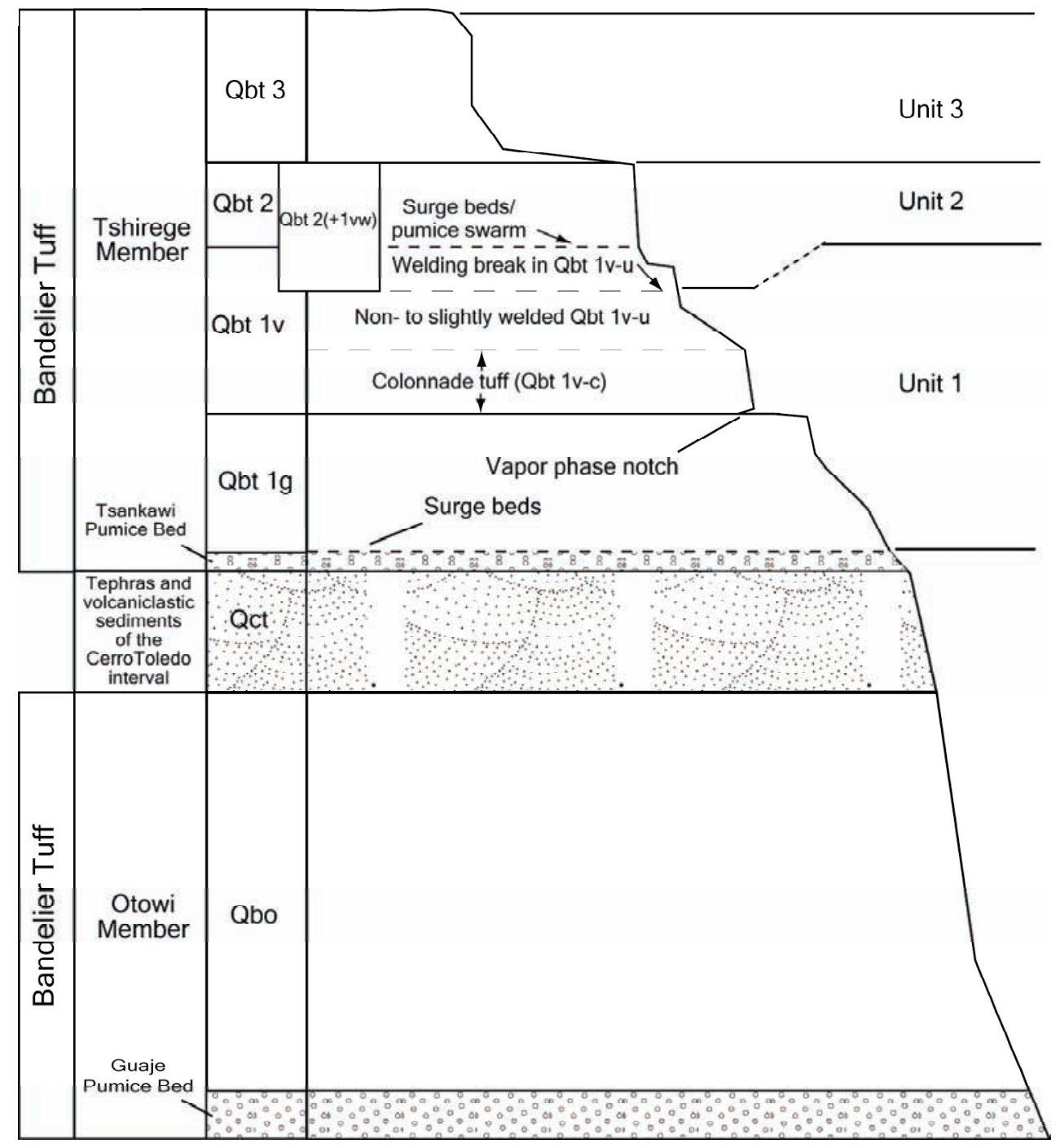

Schultz-Fellenz and Gardner

Figure 3. Generalized stratigraphy of the lower units of the Bandelier Tuff and Cerro Toledo interval exposed in the study area (from Lavine et al., 2003). Thickness of units is shown schematically and varies over the Pajarito Plateau. Unit Qbt2(+1vw) in the study area is equivalent to Qbt2 to the west (e.g., Gardner et al., 1999) and to unit $\mathrm{Qbt} 2$ and the upper part of Qbt1v-u to the east of the study area. 


\section{PREVIOUS WORK}

In 1985, J. Gardner (unpublished data) developed a Los Alamos area fault model projecting the southern termini of the Rendija Canyon and Guaje Mountain faults into LANL technical areas, including the TA-55 area (Plutonium Facility). At the time of development of this early model of the Pajarito fault system, no detailed data existed to define the southward projections of these faults with any certainty. An iteration of this unpublished fault model was obtained in 2002 by the LANL Solid Waste Regulatory Compliance Group and included within the LANL TA-50 Part B Renewal Application (LANL Solid Waste Regulatory Compliance Group, 2002). Because this early fault model was generated, and even before publication of the 2002 TA-50 report, a great deal of high-precision geologic mapping has been completed on the southern extent of the Rendija Canyon and Guaje Mountain faults. Studies by Gardner et al. (1999, 2001), Lewis et al. (2002), Lavine et al. (2003), and Lewis et al. (in review) provide detailed geologic data, particularly with respect to structure, which supersedes that presented in Figure A-5 of the TA-50, Part B, Renewal Application of 2002 (Figure 2).

Gardner et al. (1999) showed that the geometry of the surface expression of the Rendija Canyon fault, moving along-strike from north to south, begins to bend southwest at Pueblo Canyon, runs beneath the Los Alamos townsite, and continues beneath LANL's main technical area (TA-3) where a series of southwest-trending, small en-echelon faults connect the Rendija Canyon fault with the master Pajarito fault. Along the strike from north to south, the last definite surficial expression of the Guaje Mountain fault is at Bayo Canyon in the northern part of the Los Alamos townsite (Gardner et al., 2003). The high-precision surveys and geologic mapping of Gardner et al. $(1998,1999)$ have shown no vestige of the Rendija Canyon or Guaje Mountain faults in the TA-55, TA-50, or TA-52 areas.

The proposed TA-52 TRUWF is situated approximately 4 miles $(6.4 \mathrm{~km})$ east of the Pajarito fault, which is the master structure in the Los Alamos area (Figure 2). The antithetic Rendija Canyon fault is located 1.5 miles $(2.5 \mathrm{~km})$ west of TA-52, and the southernmost-mapped expression of the Guaje Mountain fault is 2.5 miles ( $4 \mathrm{~km}$ ) north of TA-52 (Figure 4). A southward projection of the Guaje Mountain fault would skirt the eastern boundary of TA-48, approximately 1 mile $(1.6 \mathrm{~km})$ west of TA-52.

\section{SITE-SPECIFIC GEOLOGIC STUDIES AT LANL}

The site of the proposed TRUWF lies near the margins of detailed geologic mapping studies completed by the LANL Seismic Hazards Geology Team (e.g., Gardner et al., 1999, 2001; Lewis et al., 2002; Lavine et al., 2003; Lewis et al., in review). Figure 4 shows the location of the proposed facility at TA-52 with respect to previous studies and geologic structures. Figure 5 shows the footprint of the proposed facility at TA-52 with respect to mapped geologic contacts and structures within both a $200-\mathrm{ft}$ and a 3,000-ft radius of the site, according to the requirements of 40 CFR 264. Additional site-specific detailed geologic studies, including trenching, mapping, fracture analyses, and borehole studies, have been completed at technical areas near the proposed facility and are addressed below in order of increasing distance from the site (after Lewis and Gardner, 2006). 

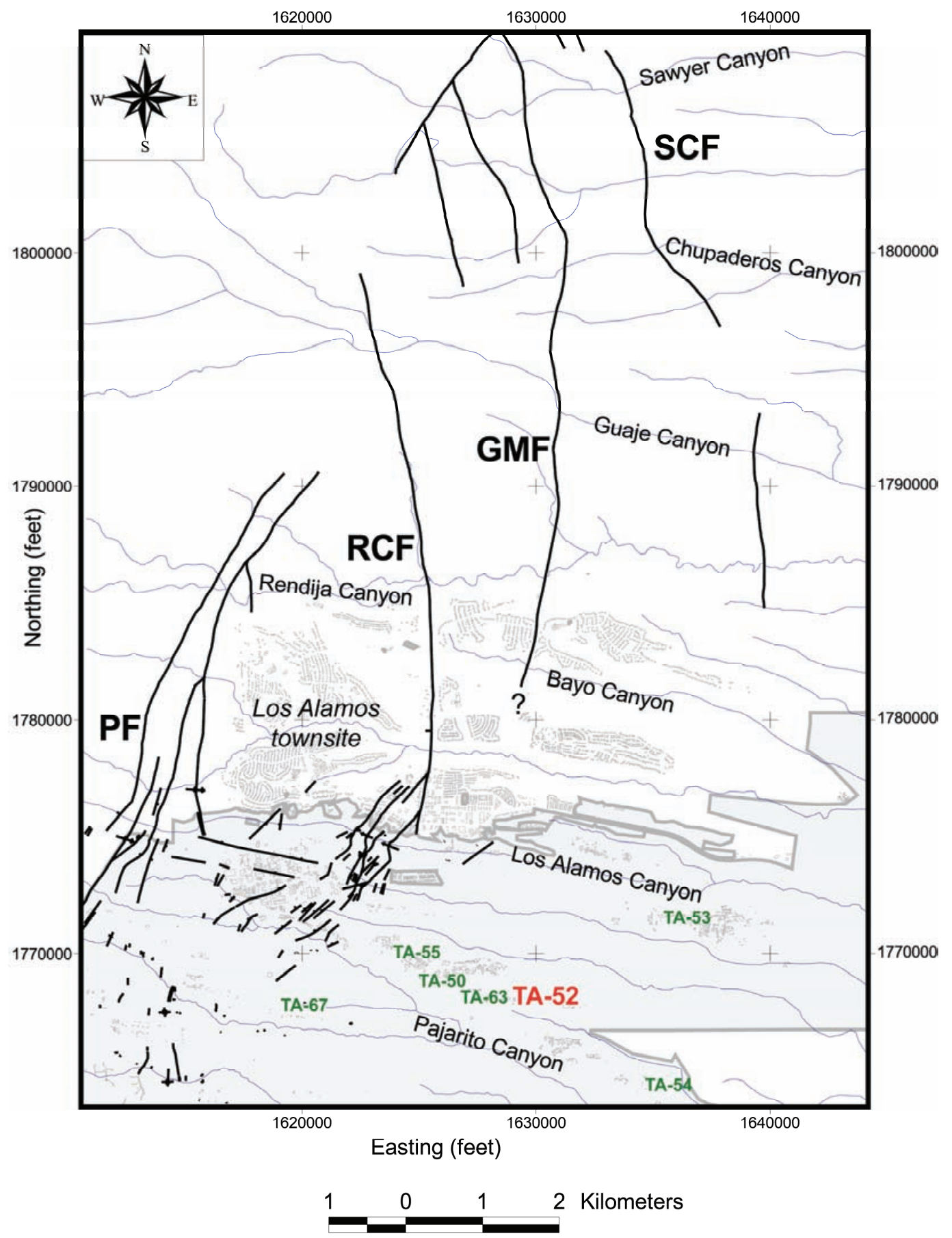

Schultz-Fellenz and Gardner

Figure 4. Pajarito fault system structural map, with emphasis on subsidiary structures associated with the system. The Pajarito fault system includes the down-to-the-west Rendija Canyon (RCF), Guaje Mountain (GMF), and Sawyer Canyon (SCF) faults, as well as the master down-to-the-east Pajarito fault (PF). Faults and related folds are shown in black. TA-52 is labeled in red. Other site-specific geologic studies conducted at LANL and discussed in Section 4 are labeled in green by technical area. Modified from Gardner et al. (2003). 

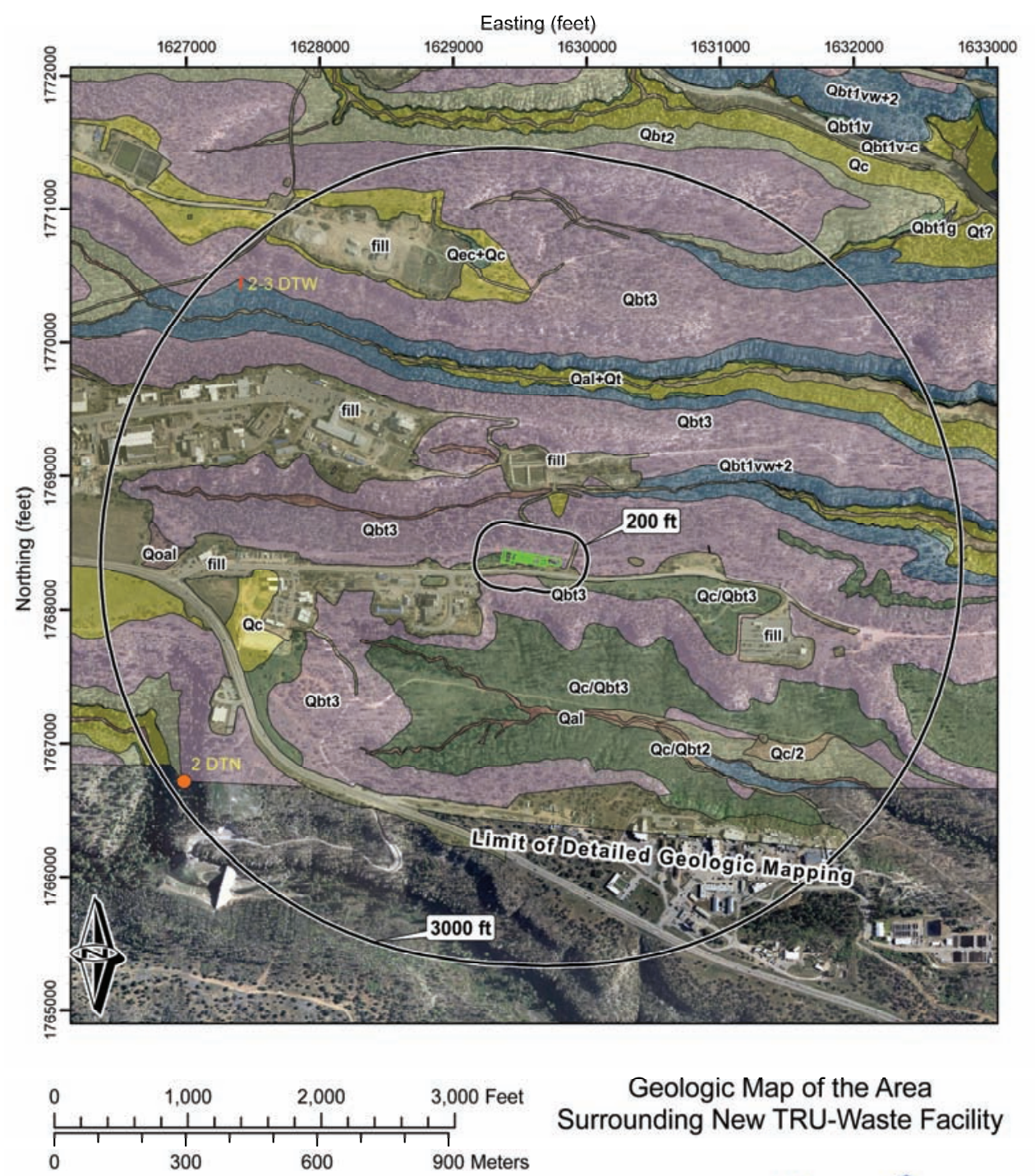

Geologic Map of the Area
Surrounding New TRU-Waste Facility
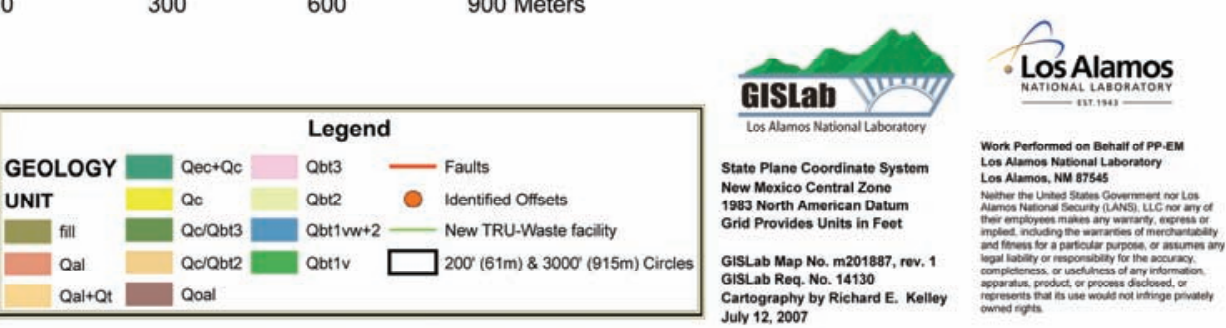

Schultz-Fellenz and Gardner

Figure 5. Localized geologic map of the TA-52 area, including 200-ft and 3,000-ft standoffs according to 40 CFR 264. Colored polygons represent different mapped geologic units (refer to Figure 3 for Bandelier Tuff stratigraphic nomenclature). Red lines represent faults; red dots represent identified displacements on Bandelier Tuff subunit contacts with no observed continuity. Numbers and letters associated with red dots and lines indicate the amount and sense of observed displacement (e.g., $2 \mathrm{DTN}=2 \mathrm{ft}$ down-to-the-north). Geologic and structural mapping are from Gardner et al. (1999), Lavine et al. (2003), and Seismic Hazards Geology Team (unpublished mapping). 


\section{IV.A. Evaluation of the Potential for Surface Faulting at TA-63}

Geologic investigations at TA-63 (Figure 4) for a proposed radioactive liquid waste treatment facility (RLWTF) included mapping, trenching, and fracture analysis (Kolbe et al., 1995). Five trenches with a total length of 2,250 ft $(685 \mathrm{~m})$ were excavated across the full extent (west to east) of TA-63 and southern parts of TA-52. Trenches were oriented perpendicular to the north-south strike of the Guaje Mountain fault, which was thought to pass within the 3,000 ft $(914 \mathrm{~m})$ envelope surrounding the proposed site. Although ubiquitous north- to north-northeaststriking subvertical fractures in the Bandelier Tuff were observed throughout the trenches, no significant increase in fracture density was noted toward or within the southward projection of the Guaje Mountain fault, and no evidence of Holocene faulting was observed. The observed fractures were documented as small tensile openings, and likely do not behave as faults. Kolbe et al. (1995) identified slickensides in a few fractures in unit Qbt3 but concluded they were a result of gravitational slip toward drainages bounding the eastern edge of the site. Additionally, the motion appeared to be quite small (on the order of a few tens of millimeters between blocks). Nevertheless, the probability of Holocene movement on fractures could not be fully discounted because of the lack of continuous late Quaternary deposits across the area of investigation. Kolbe et al. (1995) also indicated that if deformation were distributed over a wide zone, small offsets (sub-centimeter) could easily be unrecognizable in the Bandelier Tuff or post-Bandelier deposits.

\section{IV.B. Conceptual Design Report for the TA-50 Radioactive Liquid Waste Treatment Facility (RLWTF) Upgrade Project}

Kleinfelder, Inc., performed exploratory drilling of eight borings to depths of 23-26.5 ft (7.0-8.1 m) using a hollow-stem auger (DMJM H\&N, 2005). One boring was extended to a depth of $90 \mathrm{ft}(27.4 \mathrm{~m})$ for environmental purposes only. Logs indicate the presence of Bandelier Tuff at depths of 2-9 ft (0.6-2.7 m) beneath fill. Subunits of Bandelier Tuff were not distinguished in their report, and contacts between said subunits were not noted. However, all tuff in the borings appears to be poorly welded, purple to brown in color, and slightly to extensively fractured. Based on rock outcrop in the area, as well as observations from the boring logs, the tuff present in the borings is likely to be Qbt3. Unit Qbt4 is not present in outcrop at TA-50, but could be present in localized areas in the subsurface where post-Bandelier Tuff deposits have been preserved (see Kolbe et al., 1995).

\section{IV.C. Seismic Hazards Investigations at and near TA-55}

Geologic studies performed in the TA-55 area include geologic mapping and trenching (Dames and Moore, 1972; Purtymun et al., 1995; Gardner et al., 1998, 1999). As part of a geologic study of TA-55, Vaniman and Wohletz (1990) demonstrated high fracture density and large fracture apertures in Bandelier Tuff where East Jemez Road crosses the southward projection of the Guaje Mountain fault (near the intersection of East Jemez Road and La Mesita Road, the entrance to TA-53). Detailed geologic mapping of Gardner et al. $(1998,1999)$ included total station surveying of the Qbt3-Qbt4 contact along Pajarito Road, and the Qbt2-Qbt3 contact in Mortandad Canyon to the north and Twomile Canyon to the south. The most useful marker horizon for identifying small-displacement faults $[<1 \mathrm{ft}(0.3 \mathrm{~m})$ vertical displacement] in this area is the Qbt3-Qbt4 contact, which is generally quite sharp and commonly marked by a pyroclastic surge deposit. The Qbt2-Qbt3 contact is gradational over approximately $3 \mathrm{ft}(1 \mathrm{~m})$, 
and is not as useful for locating small faults. The presence of both contacts enhances the determination of the absence or presence of faulting.

Gardner et al. (1999) identified no mappable faults within the Bandelier Tuff at TA-55. The study identified a single-point location of $2 \mathrm{ft}(0.61 \mathrm{~m})$ down-to-the-north displacement on the Qbt2-Qbt3 contact, and that feature is situated near the 3,000-ft envelope and at the edge of detailed geologic mapping performed by Seismic Hazards Geology Team personnel, seen on Figure 4 of this document. Identification of small displacement on a known gradational contact, its lack of lateral continuity, and no evidence of Holocene movement support the inconsequential nature of this single-point location in an assessment of surface rupture hazard. Post-Bandelier Tuff deposits are nearly absent at TA-55, having been in large part stripped away by modern building activities and replaced with fill. Olig et al. (1996) calculated a probabilistic displacement hazard for a principal trace of the Rendija Canyon fault near its southern end as 0.67 inches $(1.7 \mathrm{~cm})$ in 10,000 years. Gardner et al. (1999) therefore determined that the potential for seismic surface rupture at TA-55 has to be extremely low because virtually no deformation in the last 1.22 million years can be documented there.

Lavine et al. (2005) examined borehole logs and cores from geotechnical drilling studies performed at the site of the proposed Chemistry and Metallurgy Research Facility Replacement (CMRR) building at TA-55 to determine whether Tshirege Member contact elevations reveal any faulting at the site. The study resulted in three-dimensional models of a surface defined by the Qbt3-Qbt4 contact and identified no significant [e.g., expressing several feet $(>1 \mathrm{~m})$ of vertical displacement] faulting.

Investigations by the EES-9 Seismic Hazards Geology Team at the site of the CMRR excavation are currently underway. These investigations include detailed examinations of the Qbt3-Qbt4 contact, the undulating pyroclastic surge deposit separating the Tshirege Member subunits, and any fracturing or structures that might be present, as well as a high-precision total station survey of identified geologic features. The pyroclastic surge exhibits radical thickness changes over short distances. Units Qbt3 and Qbt4 are intensely fractured in places, with the fractures exhibiting variable amounts of vertical continuity and displacement across the pyroclastic surge in particular. The fractures are often curvilinear and frequently terminate at the contact with the pyroclastic surge. Minor faults with less than $2 \mathrm{ft}(0.61 \mathrm{~m})$ of vertical displacement across the pyroclastic surge are present, which may represent initial cooling and compaction of the tuff shortly after emplacement 1.22 million years ago. Field investigations and detailed analysis of the geologic features at the CMRR excavation, including interpretation of their relationship (if any) to the Rendija Canyon and Guaje Mountain faults, are slated for completion in February 2008.

\section{IV.D. Surficial Materials and Structure at Pajarito Mesa, TA-67}

Exploratory trenching and surficial geologic mapping were conducted along Pajarito Mesa (Figure 4) to evaluate the potential for surface faulting at a proposed Mixed Waste Disposal Facility (Kolbe et al., 1994; Reneau et al., 1995). Trenches totaling 4,400 linear feet (1,340 m) were excavated. These trenches exposed deposits of Bandelier Tuff and a robust post-Bandelier Tuff stratigraphy. These studies concluded that active faulting on that portion of Pajarito Mesa had been absent for at least the last 50-60 kyr. Other studies focusing on fractures along the 
south edge of Pajarito Mesa (Vaniman and Chipera, 1995) showed no zones of high or increasing fracture density, nor any zones of wide fracture opening, in the locations where the Rendija Canyon or Guaje Mountain faults were believed to cross the mesa.

\section{IV.E. Fracture Characteristics in a Disposal Pit on Mesita del Buey, TA-54}

Reneau and Vaniman (1998) performed detailed total station surveys of Tshirege Member contacts on Mesita del Buey, approximately 1.1 miles $(1.7 \mathrm{~km})$ southeast of the proposed TRUWF (Figure 4), to assess the presence or absence of structure in support of contaminant transport studies. Their investigations found 37 faults with $0.1-2.1 \mathrm{ft}(5-65 \mathrm{~cm})$ of vertical displacement on surge deposits at the Qbt1v-Qbt2 contact (Figure 3) on the north wall of Pajarito Canyon. Faults in the western end of the surveyed area form two small grabens and exhibit the greatest amount of vertical displacement [3.2-6.5 ft (1-2 m) per fault on the surge between Qbt1v-Qbt2]. Faults mapped in this area have a wide range of orientations and sense of offset and form numerous horst-and-graben structures. Reneau and Vaniman (1998) inferred that faults at TA-54 were associated with deformation during paleoseismic events on the Pajarito fault or even on more regional structures, and that the small faults at TA-54 likely do not represent a major, independent fault zone.

\section{IV.F. Geology of the North-Central to Northeastern Portion of LANL, TA-53}

Geologic mapping and related field investigations, with the purpose of assessing seismic hazards in the north-central to northeastern portion of LANL including and surrounding TA-53, revealed only small faults that have little potential for seismic surface rupture (Lavine et al., 2003). These small faults lie east of the Pajarito fault system, show no clear connectivity to the Sawyer Canyon fault or other mapped or inferred structures, and likely represent subsidiary distributed faulting associated with earthquakes occurring on the Pajarito fault system.

\section{EFFICACY OF FUTURE PALEOSEISMIC STUDIES AT SITE OF THE PROPOSED TA-52 TRUWF}

The area of detailed geologic mapping by Lavine et al. (2003) and by the Seismic Hazards Geology Team (unpublished mapping) includes the footprint of the proposed TRUWF. The studies identified no laterally continuous geologic structures in the area. Geologic units exposed on the surface at the mesa top are primarily Qbt3, covered in some areas with thin colluvium (Figure 5). Qbt3 is at least $40 \mathrm{ft}(\sim 12 \mathrm{~m})$ thick in this location. No post-Bandelier Tuff deposits were identified, and recent field reconnaissance confirms the lack of significant post-Bandelier Tuff deposits in the area. Such deposits were never deposited, have been stripped by geomorphic processes over time, or have been removed by anthropogenic activities at the TA-52 site.

The absence of a robust sequence of post-Bandelier Tuff stratigraphy overlying Qbt3 in this location creates significant difficulty in embarking on future paleoseismic studies near the TRUWF footprint at TA-52. Without such units, the ability to identify paleoseismic events that postdate the deposition of the tuff (i.e., Holocene events) and to establish ages for identifiable paleoevents is essentially eliminated. Investigating the Qbt3-Qbt2 contact is not feasible as a trenching study. An alternative to shallow trenching would be to excavate or drill to the Qbt3-Qbt2 contact, which is at least $40 \mathrm{ft}(\sim 12 \mathrm{~m})$ below the ground surface at the proposed TRUWF. A further complication to assessment of faulting using the Qbt3-Qbt2 contact, as opposed to using other Tshirege Member subunit contacts, is that the Qbt3-Qbt2 contact is 
marked by a gradational increase in welding downsection [over 1.5-3ft $(0.5-1 \mathrm{~m})$ ] from nonwelded unit Qbt3 to moderately- to partially-welded unit Qbt2. The gradational nature of the Qbt3-Qbt2 contact limits its usefulness in identifying small-offset faults and establishes only an approximate offset on larger structures. Given this geologic dataset, identification of the presence of Holocene faults in the TA-52 area through trenching or drilling could not be definitively ascertained.

\section{CONCLUSIONS}

Detailed geologic studies done at technical areas near TA-52 identified no evidence for significant, laterally continuous Holocene faulting near the proposed facility site. Trenches at TA-67 identified no active faults younger than 50-60 kyr. Fault studies at TA-53 showed subsidiary structures with very small offsets and small potential for surface rupture. Geologic investigations at TA-55 have thus far shown no evidence for Holocene faults; detailed fracture and fault analyses are currently ongoing in support of the CMRR facility with results forthcoming. A detailed total station survey at TA-54 recognized numerous small-offset faults that represent distributed hangingwall deformation from events on the principal Pajarito fault, but did not show independent Holocene movement. However, at TA-55 and TA-63, the post-Bandelier Tuff stratigraphy was thin to absent, and therefore the presence of Holocene faults could not be absolutely confirmed or discounted. Generally, surface rupture potential is highest in close proximity to the major structures in the Pajarito fault system, those being the Pajarito, Rendija Canyon, and Guaje Mountain faults. Given the distal location of the proposed TRUWF to any mapped structures with demonstrable Holocene displacement, surface rupture potential appears quite low at TA-52. Additionally, two small-displacement $(2 \mathrm{ft}[0.61 \mathrm{~m}])$ features were identified on the Qbt2-Qbt3 contact within the 3,000-ft envelope surrounding the TA-52 facility (see Figure 5). The features were identified on a known gradational contact of two Bandelier Tuff subunits, meaning that uncertainty on any identified offsets is high. Additionally, the features lack lateral continuity, and no evidence was found demonstrating that offset on the features was generated as a result of a Holocene seismic event. This reaffirms the low potential for surface rupture at TA-52.

Although the Pajarito and Rendija Canyon faults have been mapped in detail for their full along-strike distance in the vicinity of LANL, the southern end of the Guaje Mountain fault has not been mapped in detail. Although its defined surface expression ends at Bayo Canyon, displacements of Bandelier Tuff subunit contacts $\sim 10 \mathrm{ft}(\sim 3 \mathrm{~m})$ down-to-the-west were identified on the north side of Pueblo Canyon, approximately 1.75 miles $(\sim 2.8 \mathrm{~km})$ north of the TA-52 site (Lavine and Schultz-Fellenz, unpublished mapping). The absolute location of the Guaje Mountain fault near the proposed TA-52 TRUWF, and its southernmost termination, are not known; however, detailed geologic studies in technical areas surrounding TA-52 (including TA-55, TA-63, TA-53, and TA-54) found no clear evidence of the Guaje Mountain fault in those areas. Geologic investigations near the TA-52 TRUWF site suggest that the potential for seismic surface rupture is likely to be extremely minimal.

\section{ACKNOWLEDGMENTS}

This work was supported by the Environmental Management (EM) Group of the Program Projects (PP) Division and by planning efforts for a proposed TRUWF. We thank Lee Lucero, Bruce Masse, and Jack Ellvinger for help with coordination of this project. Rick Kelley of 
LANL's Geographic Information System Laboratory provided invaluable assistance with cartography and database management. Doug Volkman and Alexis Lavine contributed helpful reviews of early iterations of this report.

\section{REFERENCES}

Baldridge, W.S., Dickerson, P.W., Riecker, R.E., and Zidek, J. (eds.), 1984. Rio Grande Rift: Northern New Mexico. New Mexico Geological Society Guidebook 35, 379 pp.

Baldridge, W.S., Keller, G.R., Haak, V., Wendlandt, E., Jiracek, G.R., and Olsen, K.H., 1995. The Rio Grande rift. In Continental Rifts: Evolution, Structure, Tectonics, Olsen, K.H., editor, pp.233-275. Amsterdam, Holland: Elsevier.

Broxton, D.E., and Reneau, S.L., 1995. Stratigraphic nomenclature of the Bandelier Tuff for the Environmental Restoration project at Los Alamos National Laboratory. Los Alamos National Laboratory report LA-13010-MS, 21 pp.

Dames and Moore, 1972. Report of geological foundation, hydrologic and seismic investigation, Plutonium Processing Facility, Los Alamos Scientific Laboratory. Unpublished consulting report prepared for the Atomic Energy Commission by Dames and Moore, Inc., Los Angeles, CA.

DMJM H\&N, 2005. Conceptual design report for the TA-50 Radioactive Liquid Waste Treatment Facility (RLWTF) upgrade project. Unpublished consulting report prepared for LANL by DMJM H\&N, 1 volume.

Gardner, J.N., Baldridge, W.S., Gribble, R., Manley, K., Tanaka, K., Geissman, J.W., Gonzalez, M., and Baron, G., 1990. Results from seismic hazards trench \#1 (SHT-1), Los Alamos Seismic Hazards Investigations. Los Alamos National Laboratory unpublished document EES1-SH90-19.

Gardner, J.N., Lavine, A., Vaniman, D., and WoldeGabriel, G., 1998. High-precision geologic mapping to evaluate the potential for seismic surface rupture at TA-55, Los Alamos National Laboratory. Los Alamos National Laboratory report LA-13456-MS, 13 pp.

Gardner, J.N., Lavine, A., WoldeGabriel, G., Krier, D., Vaniman, D., Caporuscio, F., Lewis, C.J., Reneau, P., Kluk, E., and Snow, M.J., 1999. Structural geology of the northwestern portion of Los Alamos National Laboratory, Rio Grande rift, New Mexico: Implications for seismic surface rupture potential from TA-3 to TA-55. Los Alamos National Laboratory report LA-13589-MS, 112 pp.

Gardner, J.N., Reneau, S.L., Lewis, C.J., Lavine, A., Krier, D., WoldeGabriel, G., and Guthrie, G., 2001. Geology of the Pajarito fault zone in the vicinity of S-Site (TA-16), Los Alamos National Laboratory, Rio Grande rift, New Mexico. Los Alamos National Laboratory report LA-13831-MS, 86 pp.

Gardner, J.N., Reneau, S.L., Lavine, A., Lewis, C J., Katzman, D., McDonald, E.V., Wilson, J., Goodwin, L., Kelson, K.I., Lepper, K., and Wilson, C., 2003. Paleoseismic trenching in the Guaje Mountain fault zone, Pajarito fault system, Rio Grande rift, New Mexico. Los Alamos 
National Laboratory report LA-14087-MS, 68 pp.

Izett, G.A., and Obradovich, J.D., 1994. ${ }^{40} /{ }^{39} \mathrm{Ar}$ age constraints for the Jaramillo normal subchron and the Matuyama-Brunhes geomagnetic boundary. J. Geophys. Res. 99 (B2), pp. 2925-2934.

Kelley, V.C., 1979. Tectonics, middle Rio Grade rift, New Mexico. In Rio Grande Rift:

Tectonics and Magmatism, R.E. Riecker, ed. (American Geophysical Union, Washington, D.C.), pp. 57-70.

Kelson, K.I., and Olig, S.S., 1995. Estimated rates of Quaternary crustal extension in the Rio Grande rift, northern New Mexico. New Mexico Geological Society Guidebook 46, pp. 9-12.

Kelson, K.I., Hemphill-Haley, M.A., Olig, S.S., Simpson, D., Gardner, J.N., Reneau, S.L., Kolbe, T.R., Forman, S.L., and Wong, I.G., 1996. Late-Pleistocene and possibly Holocene displacement along the Rendija Canyon fault, Los Alamos County, New Mexico. New Mexico Geological Society Guidebook 47: 153-160.

Kolbe, T., Sawyer, J., Gorton, A., Olig, S., Simpson, D., Fenton, C., Reneau, S., Carney, J., Bott, J., and Wong, I., 1994. Evaluation of the potential for surface faulting at the proposed Mixed Waste Disposal Facility, TA-67. Unpublished consulting report prepared for LANL by Woodward-Clyde Federal Services, Oakland, CA, 3 volumes.

Kolbe, T., Sawyer, J., Springer, J., Olig, S., Reneau, S., Hemphill-Haley, M., and Wong, I., 1995. Evaluation of the potential for surface faulting at TA-63. Unpublished consulting report prepared for LANL by Woodward-Clyde Federal Services, Oakland, CA, 1 volume.

LANL Seismic Hazards Geology Team. In prep. Review and reevaluation of paleoseismic event chronology from the Pajarito fault system, Los Alamos, New Mexico, 33 pp.

Lavine, A., Lewis, C.J., Katcher, D., and Wilson, J., 2003. Geology of the north-central to northeastern portion of Los Alamos National Laboratory, New Mexico. Los Alamos National Laboratory report LA-14043-MS, 44 pp.

Lavine, A., Gardner, J.N., and Schultz-Fellenz, E.S., 2005. Evaluation of faulting at the Chemistry and Metallurgy Facility Replacement (CMRR) Site based on examination of core from geotechnical drilling studies, TA-55, Los Alamos National Laboratory. Los Alamos National Laboratory report LA-14170-MS, 21 pp.

Lewis, C.L., and Gardner, J.N., 2006. Preliminary review of literature on geologic studies near the site of the Proposed Radioactive Liquid Waste Treatment Facility, TA-50, Los Alamos National Laboratory, New Mexico. Informal report, Los Alamos National Laboratory, Los Alamos, NM.

Lewis, C.J., Lavine, A., Reneau, S.L., Gardner, J.N., Channell, R., and Criswell W., 2002. Geology of the western part of Los Alamos National Laboratory (TA-3 to TA-16), Rio Grande rift, New Mexico. Los Alamos National Laboratory report LA-13960-MS, 98 pp. 
Lewis, C.J., Gardner, J.N., Schultz-Fellenz, E.S., Lavine, A., Olig, S., and Reneau, S.L., In review. Lateral displacement variation and fault interaction in the Pajarito fault system, Rio Grande rift, New Mexico; submitted to Geosphere.

Los Alamos National Laboratory Solid Waste Regulatory Compliance (SWRC) Group, 2002. Los Alamos National Laboratory Technical Area 50 Part B Renewal Application, Revision 3.0. Unpublished permit application prepared for the New Mexico Environment Department by SWRC, Los Alamos, NM. 191 pp.

McCalpin, J.P., 1998. Late Quarternary faulting on the Pajarito fault, west of Los Alamos National Laboratory, north-central New Mexico: Results from the seven-trench transect excavated in summer of 1997. Unpublished consulting report prepared for Los Alamos National Laboratory by GEO-HAZ Consulting, Inc., Estes Park, CO.

McCalpin, J.P., 1999. Late Quaternary faulting on the Pajarito fault, west of Los Alamos National Laboratory, north-central New Mexico: Results from seven trenches excavated in summer 1998. Unpublished consulting report prepared for Los Alamos National Laboratory by GEO-HAZ Consulting, Inc., Estes Park, CO.

Olig, S.S., Kelson, K.I., Gardner, J.N., Reneau, S.L., and Hemphill-Haley, M., 1996. The earthquake potential of the Pajarito fault system, New Mexico. New Mexico Geological Society Guidebook 47: 143-151.

Purtymun, W.D., Koenig, E., Morgan, T., and Sagan, E., 1995. Joint orientation and characteristics as observed in a trench excavated near TA-3 and a basement excavated at TA-55. Los Alamos National Laboratory report LA-13036-MS, 42 pp.

Reneau, S.L., and Vaniman, D.T., 1998. Fracture characteristics in a disposal pit on Mesita del Buey, Los Alamos National Laboratory. Los Alamos National Laboratory report LA-13539-MS, $21 \mathrm{pp}$.

Reneau, S.L., Kolbe, T., Simpson, D., Carney, J., Gardner, J., Olig, S., and Vaniman, D., 1995. Surficial materials and structure at Pajarito Mesa. In Geological Site Characterization for the Proposed Mixed Waste Disposal Facility, Reneau, S.L., and Raymond, R., Jr., eds. Los Alamos National Laboratory report LA-13089-MS, pp. 31-69.

Reneau, S.L., Gardner, J.N., Lavine, A., McDonald, E.V., Lewis, C.J., Katzman, D., WoldeGabriel, G., Krier, D., Bergfeld, D., and Heikoop, J., 2002. Paleoseismic investigation of trench EOC-2, Pajarito fault zone, Los Alamos National Laboratory, New Mexico. Los Alamos National Laboratory report LA-13939-MS, 65 pp.

Riecker, R.E., Ed., 1979. Rio Grande Rift: Tectonics and Magmatism. (American Geophysical Union, Washington, D. C.), 438 pp.

Sanford, A.R., Jaksha, L.H., and Cash, D.J., 1991. Seismicity in the Rio Grande rift. In Neotectonics of North America, Decade Map, Vol. 1, D.B. Slemmons, E.R. Engdahl, E.M.D. Zobeck, and D.D. Blackwell, eds. (Geological Society of America, Boulder, CO), pp. 229-244. 
Schultz, E.S., Lewis, C.J, Lavine, A. Gardner, J.N., and Reneau, S.L., 2003. Along-strike variation in a faulted monocline, Pajarito fault, Los Alamos, New Mexico. Geological Society of America Abstracts with Programs 34 (7), pp. 581-582.

Vaniman, D., and Wohletz, K., 1990. Results of geological mapping/fracture studies: TA-55 area. Los Alamos National Laboratory Seismic Hazards program memorandum EES1-SH90-17, (3 plates, 23 figures), $25 \mathrm{pp}$.

Vaniman, D., and Chipera, S., 1995. Mesa-penetrating fractures, fracture mineralogy, and fault traces at Pajarito Mesa. In Geological Site Characterization for the Proposed Mixed Waste Disposal Facility, Reneau, S.L., and Raymond, R., Jr., eds. Los Alamos National Laboratory report LA-13089-MS, pp. 71-85.

Wolff, J.A., and Gardner, J.N., 1995. Is the Valles caldera entering a new cycle of activity? Geology 23, pp. 411-414.

Wong, I., Kelson, K., Olig, S.S., Kolbe, T., Hemphill-Haley, M., Bott, J., Green, R., Kanakari, H., Sawyer, J., Silva, W., Stark, C., Haraden, C., Fenton, C., Unruh, J., Gardner, J.N., Reneau, S.L., and House, L., 1995. Seismic hazards evaluation of the Los Alamos National Laboratory. Unpublished consulting report prepared for Los Alamos National Laboratory by Woodward-Clyde Federal Services, Oakland, CA, 3 volumes. 
This report has been reproduced directly from the best available copy. It is available electronically on the Web (http://www.doe.gov/bridge).

Copies are available for sale to U.S. Department of Energy employees and contractors from:

Office of Scientific and Technical Information

P.O. Box 62

Oak Ridge, TN 37831

(865) 576-8401

Copies are available for sale to the public from: National Technical Information Service

U.S. Department of Commerce

5285 Port Royal Road

Springfield, VA 22161

(800) 553-6847 
- Los Alamos NATIONAL LABORATORY

EST.1943 